\title{
Clinical and Biological Profile of Patients with Non-Valvular Atrial Fibrillation and Hemodynamic Significant Valvular Heart Disease
}

\author{
IULIANA ARDELEANUㄴ, MARIANA FLORIA*, OANA VIOLA BADULESCU2*, IRIS BARARU BOJAN², MARIA VLADEANU², \\ LARISA ANGHEL ${ }^{1}$, ANA TANASE ${ }^{1}$, LIVIU MACOVEI ${ }^{1}$, CRISTIAN STATESCU ${ }^{1}$, MANUELA CIOCOIU ${ }^{2}$, PAUL DAN SIRBU ${ }^{3 *}$, \\ CATALINA ARSENESCU GEORGESCU ${ }^{1}$ \\ ${ }^{1}$ Grigore T. Popa University of Medicine and Pharmacy, Department of Internal Medicine, 16 Universitatii Str., 700115, lasi, \\ Romania \\ ${ }^{2}$ Grigore T. Popa University of Medicine and Pharmacy, Faculty of Medicine, Department of Pathophysiology, Morfo-Functional \\ Sciences (II), 16 Universitatii Str., 700115, Iasi, Romania \\ ${ }^{3}$ Grigore T. Popa University of Medicine and Pharmacy, Faculty of Medicine, Department of Orthopedics and Traumatology, \\ Surgical Sciences (II), 16 Universitatii Str., 700115, lasi, Romania
}

\begin{abstract}
The non-valvular $A F$, beyond the guidelines, include 2 types of patients. We aimed to analyze the clinical and biological profile of patients with non-valvular atrial fibrillation (AF)andhemodynamicsignificantvalvular heart disease. We includedretrospectively 513 patients admitted in our hospitalwithnon-valvular $A F$, and we divided into:study group(333 patients; 64.9\%) andcontrole group(180 patients; 35.1\%) hemodynamic significant valvular heart disease. From the studied group 5.5\% of patients associated all four valvular heart disease, $26.7 \%$ ofpatients associated mitral, aortic and tricuspid regurgitation and $71.9 \%$ of patients associated two valvular heart disease: $32.7 \%$ with mitral and aortic, 31.4\% with mitral and tricuspid, $4.5 \%$ with tricuspid and pulmonary, and3.3\% withtricuspid and aortic. Dyslipidemia (higher cholesterol and trygliceride levels) was present in $14.5 \%$ of patients, statistic significantly more frequently in patients from the control group (11.4\% vs $18.3 \%, P=0.033)$. Dyslipidemia showed a significantly higher estimated risk for $A F(R R=1.25$; IC95\%: 0.99-1.56), as well as diabetes mellitus (RR=1.36; IC95\%: 1.12-1.64)and coronary heart disease ( $R R=3.70$; IC95\%: 1.83-7.46). Therefore patients with non-valvular AF and hemodynamic significant valvular heart disease, beyond the curent guidelines, could has a completely different profile and prognosis.
\end{abstract}

Keywords:Atrial Fibrillation; Non-valvular;Valve Disease;Hemodynamicaly Significant;dyslipidemia

Atrial fibrillation (AF) is the most common sustained cardiac arrhythmia, occurring in 1-2\% of the general population, and its prevalence is estimated to double in the next 50 years as the population ages [1-3].

Due to the predominance of degenerative etiology, the most common valvulopathies are aortic stenosis (AS) and mitral regurgitation (MR), while aortic regurgitation (AR) and mitral stenosis (MS) are less common [3,4].Mitral valvulopathies (stenosis and regurgitation) significantly increase the risk of $A F$, which generates favorable conditions for thrombogenesis [5-8]. The meaning of valvular AF (or non-valvular) is far from clear to cardiologists and internists who deal with AF [11].In patients with non-valvular AF thromboembolic risk assessement is based on CHA2DS2VASc score[12,13].The objective of the study was to fiind the clinicaland biological profile of patients with nonvalvular AF and hemodynamic significant valvular heart disease beyond the guidelines definition of valvular $\mathrm{AF}$ $[9,10]$.

\section{Experimental part}

Patients and data collection

Inthis retrospective observational study we included all patients admitted in our hospital during 6 month, with nonvalvular AF.

Valvular AF was defined as AF associated with rheumatic mitral stenosis and valvular prostheses (mechanical or bioprosthetic) or mitral valve repair (annuloplasty with or without prosthetic ring, commissurotomy and/or valvuloplasty) $[1,9,10]$.

The inclusion criteria were: patients older than 18 years, with documented non-valvular AF(associated or not with hemodynamic significant valve disease, but which does not meet the criteria for valvular AF defined by the current guidelines[ $[1,9,10]$, referred to our hospital, regardless of arrhythmia type: paroxysmal, persistent or permanent.

The exclusion criteria were: patients with valvular AF; patients with major contraindications to oral anticoagulation; patients with chronic kidney disease with creatinine clearance $<30 \mathrm{~mL} / \mathrm{min}$, pacemaker or automatic implantable cardioverter-defibrillator, hyperthiroidia, neoplasia.

The patients with non-valvular AF included in the study was divided into two groups depending on the presence of significant hemodynamic valvular heart disease: the study group- patients with significant hemodynamic valvular heart disease (mitral, aortic, tricuspid or pulmonary regurgitation II-IV degree; mild/moderate/severe aortic stenosis) and the control group- patients without significant hemodynamic valvular heart disease.Non-valvular AF was documented by standard ECG in 12 leads and/or $24 \mathrm{~h} \mathrm{ECG}$ Holter monitoring.

After a detailed medical history the following clinical parameters were noted: age, sex, smoker status, obesity (defined as body mass index - BMI - higher than $30 \mathrm{~kg} / \mathrm{m}^{2}$ ), comorbidities (dyslipidemia, hypertension, aortic atheroma plaques, diabetes mellitus, heart failure, ischemic heart disease and peripheral arterial disease).

\section{Laboratory measurements}

All laboratory measurements were performed on fasting blood samples. The biological tests evaluated were: total cholesterol, high densitylipoprotein cholesterol (HDL-col), low density lipoprotein cholesterol (LDL-col), triglyceride,

\footnotetext{
*email: floria_mariana@yahoo.com; violabadulescu@yahoo.com; pdsirbu@yahoo.com.
} 
alanine aminotransferase (ALT), aspartate aminotransaminase (AST), blood glucose, creatinine, $C$ reactive protein (CRP), tiroid stimulating hormone (TSH).

\section{Echocardiography measurements}

Echocardiographic measurements were assessed by bidimensional transthoracic echocardiography with an Acuson Sequoia 256 Ultrasound Machine (Siemens). All patients underwent standardized transthoracic twodimensional echocardiography evaluation. The echocardiographic parameters assessed during hospitalization were related to valvesmorphology and function. In patients eligible for the study valvular regurgitation was scored from 0 through 5: $0=$ no regurgitation, $1=$ mild, $2=$ mild-moderate, $3=$ moderate $4=$ severe. Grades 2-4 were considered significant. Similarly, stenosisseverity was assessed as: $0=$ no stenosis, 1 = mild stenosis, 2 = moderate stenosis, $3=$ severe stenosis. For aortic valve, all degree of severitywere considered hemodynamically significant.In accordance with the inclusion criteria, only mitral stenosis patients were included in the study.

This study has been performed in compliance with the ethical principles of the hospital and University Ethics Committee. Informed consent was obtained from each patient before the inclusion in the study. This study conforms to the Declaration of Helsinki.

\section{Statistical analysis}

Normal distribution of variables was evaluated using the Kolmogorov-Smirnov test. Categorical data are presented as frequencies and percentages; continuous variables are expressed as mean \pm standard deviation. We use for the statistical evaluation the following tests: ANOVA test consisted in analyzing the dispersion of the dependent variable: intro and intergroup, the coefficient of variation (CV\%), the t-Student test, the Kruskal-Wallis correlation and the Pearson $(r)$ coefficient. All statistical tests were two-tailed and performed with SPSS 18.0 (SPSS Inc., Chicago, IL, USA). A $P$-value $<0.05$ was set as statistical significance.

\section{Results and discussions}

We included 513 consecutive patients with mean age of $69.33 \pm 10.23$ years in the study: $48.9 \%$ with permanent $A F, 16 \%$ with persistent $A F$, and $35.1 \%$ with paroxysmal AF.Almost two third of patients (333 patients; 64.9\%) were included in the study group (AF and significant hemodynamic valvular heart disease)and one third (180 patients; 35.1\%) in the control group (AF without significant hemodynamicvalvular heart disease).

\section{Clinical parameters}

Demographic and valve disease distribution in the study population are shown in table 1.
The most frequent valvular heart disease was MR ( $75 \%)$, and moderate degree was most frequently reported (32.2\%). Tricuspid regurgitation was noted in $67.6 \%$ of patients, particularly with moderate degree (35.9\%). Twenty eight patients (5.5\%) associated all valve disease (mitral, aortic, tricuspid and pulmonary), 137 patients

Table 1

DEMOGRAPHIC PARAMETERS AND VALVULAR HEART DISEASE DISTRIBUTION IN THE STUDY POPULATION

\begin{tabular}{|c|c|}
\hline PARAMETER & $\mathrm{N}(\%)$ \\
\hline Mean age (mean \pm SD), years & $69.3 \pm 10.2$ \\
\hline Men, n (\%) & $290(56.5)$ \\
\hline Smokers, n (\%) & $\Pi 11(21.6)$ \\
\hline Alcohol consumers, n (\%) & $64(12.5)$ \\
\hline \multicolumn{2}{|c|}{ Mitral regurgitation } \\
\hline II degree, $\mathbf{n}(\%)$ & $165(32.2)$ \\
\hline III degree, $\mathbf{n}(\%)$ & $62(12.1)$ \\
\hline IV degree, $\mathbf{n}(\%)$ & $9(1.8)$ \\
\hline \multicolumn{2}{|c|}{ Aortic regurgitation } \\
\hline II degree, $\mathbf{n}(\%)$ & $76(14.8)$ \\
\hline III degree, $\mathbf{n}(\%)$ & $13(2.5)$ \\
\hline \multicolumn{2}{|c|}{ Tricuspid regurgitation } \\
\hline II degree, $\mathrm{n}(\%)$ & $184(35.9)$ \\
\hline III degree, $\mathbf{n}(\%)$ & $56(10.9)$ \\
\hline IV degree, $n(\%)$ & $5(1.0)$ \\
\hline \multicolumn{2}{|c|}{ Pulmonary regurgitation } \\
\hline I degree, $\mathbf{n}(\%)$ & $45(8.7)$ \\
\hline II degree, $\mathbf{n}(\%)$ & $12(2.3)$ \\
\hline
\end{tabular}

(26.7\%) associated MR, AR and TR and 369 patients (71.9\%) associated two valve regurgitation.

The patients from the study groupwere statistically significant older than 70 years, less often smokers and obese(table 2).

Distribution by age group revealed that the majority of patients from the study group (42\%) was in decade 70-79 years, while the majority of patients from the control group $(40 \%)$ was in decade $60-69$ years $(P=0.001)$. The percentage of patients with valvular heart disease was significantly higher in older age (Chi-square $=30,54 ; d f=5$; $P=0.001$ ).

The gender distribution was relatively homogeneous; male patients were more frequentinthe both groups. The evaluation of cardiovascular risk factors (as shown in table 3) showed that arterial hypertension was present in $61.5 \%$ of patients, without significant differences in the study group $(59.8 \%$ vs $56.7 \%, P=0.498)$. Diabetes mellitus was in $21.3 \%$ of the patients, being significantly more common in patients form the control group ( $31.1 \%$ vs $17.4 \%, \mathrm{P}=$ 0.011).

Dyslipidemia was present in $14.5 \%$ of patients, statistic significantly more frequently in patients from the control group $(11.4 \%$ vs $18.3 \%, P=0.033)$. Diabetes mellitus $(R R=$ 1.36; IC95\%: 1.12-1.64), dyslipidemia ( $R R=1.25$; IC95\%: $0.99-1.56)$ and coronary heart disease $(R R=3.70 ;$ IC95\%:

Table 2

DEMOGRAPHIC PARAMETERS OF THE STUDY SUBGROUPS

\begin{tabular}{|c|c|c|c|c|c|c|c|c|c|c|c|c|}
\hline & \multicolumn{2}{|c|}{ TOTAL } & \multicolumn{10}{|c|}{ PARAMETERS } \\
\hline & $\mathrm{N}$ & $\%$ & Men & $\%$ & $\begin{array}{l}\geq 70 \\
\text { years }\end{array}$ & $\%$ & Smoker & $\%$ & Alcohol & $\%$ & Obesity & $\%$ \\
\hline $\begin{array}{l}\text { STUDY } \\
\text { GROUP }\end{array}$ & 333 & 64.9 & 178 & 53.5 & 203 & 61.0 & 63 & 18.9 & 36 & 10.8 & 71 & 21.3 \\
\hline $\begin{array}{l}\text { CONTROL } \\
\text { GROUP }\end{array}$ & 180 & 35.1 & 112 & 62.2 & 68 & 37.8 & 48 & 26.7 & 28 & 15.6 & 57 & 31.7 \\
\hline \multicolumn{3}{|c|}{ Chi2 test (p value) } & \multicolumn{2}{|c|}{0.069} & \multicolumn{2}{|c|}{0.001} & \multicolumn{2}{|c|}{0.044} & \multicolumn{2}{|c|}{0.126} & \multicolumn{2}{|c|}{0.050} \\
\hline
\end{tabular}


Table 3

CLINICAL PARAMETERS OF THE STUDY GROUPS AND RELATIVE RISK FOR ATRIAL FIBRILLATION

\begin{tabular}{|c|c|c|c|c|c|c|c|}
\hline \multirow[t]{2}{*}{ COMORBIDITY } & \multirow{2}{*}{$\begin{array}{l}\text { STUDY GROUP } \\
\mathrm{N}=333 \\
\mathrm{n}\end{array}$} & \multicolumn{3}{|c|}{$\begin{array}{l}\text { CONTROL } \\
\text { GROUP } \\
\text { N=180 }\end{array}$} & \multicolumn{3}{|c|}{$\begin{array}{c}\text { RELATIVE RISK FOR } \\
\text { ATRIAL } \\
\text { FIBRILLATION }\end{array}$} \\
\hline & & $\mathrm{n}$ & $\mathrm{CHI}^{2}$ & $\mathrm{P}$ & OR & $R R$ & IC95\% \\
\hline Hypertension, $\mathbf{n}(\%)$ & $199(59.8)$ & $102(56.7)$ & 0.46 & 0.498 & 1.05 & 0.96 & $0.84-1.27$ \\
\hline $\mathrm{DM}, \mathbf{n}(\%)$ & $58(17.4)$ & $56(31.1)$ & 12.3 & 0.001 & 0.56 & 1.36 & $1.12-1.64$ \\
\hline Dyslipidemia, n (\%) & $38(11.4)$ & $33(18.3)$ & 4.55 & 0.033 & 0.62 & 1.25 & $0.99-1.56$ \\
\hline $\mathrm{CHD}, \mathrm{n}(\%)$ & $11(3.3)$ & $22(12.2)$ & 14,0 & 0.001 & 0,25 & 3,70 & $1,83-7,46$ \\
\hline Apnea/COPD, n (\%) & $27(8.1)$ & $17(9.4)$ & 0.26 & 0.608 & 0.86 & 1.06 & $0.83-1.36$ \\
\hline Anemia, n (\%) & $6(1.8)$ & $1(0.6)$ & 1.56 & 0.212 & 3.00 & 0.75 & $0.55-1.03$ \\
\hline VA, n (\%) & $9(2.7)$ & $2(1.1)$ & 1.55 & 0.214 & 0.56 & 0.79 & $0.59-1.05$ \\
\hline Stroke/TIA, n (\%) & $7(2.1)$ & $5(2.8)$ & 0.23 & 0.633 & 0.70 & 1.12 & $0.69-1.81$ \\
\hline Hyperthyroidism, n (\%) & $12(3.6)$ & $6(3.3)$ & 0.03 & 0.873 & 0.98 & 0.97 & $0.70-1.36$ \\
\hline Hypothyroidism, n (\%) & $17(5.1)$ & $16(8.9)$ & 2.67 & 0.102 & 0.57 & 1.28 & $0.91-1.79$ \\
\hline
\end{tabular}

CHD: coronary heart disease; DM: diabetes mellitus; TIA: transient ischemic attack; VA: ventricular arrhythmias.

Table 4

BIOLOGICAL PARAMETERS OF THE STUDY SUBGROUPS: I = STUDY GROUP, $\|=$ CONTROL GROUP

\begin{tabular}{|c|c|c|c|c|c|c|}
\hline PARAMETER & Group & $\mathrm{N}$ & Average & $\begin{array}{l}\text { Standard } \\
\text { deviation }\end{array}$ & $\begin{array}{l}\text { Confidence } \\
\text { Interval } \\
\qquad 95 \%\end{array}$ & $\begin{array}{c}\text { Test } \mathrm{F} \\
(\mathrm{ANOVA}) \mathrm{p}\end{array}$ \\
\hline \multirow[t]{2}{*}{ Cholesterol (mg/dL) } & $\mathrm{T}$ & 323 & 172.61 & 42.42 & 167.97 & \multirow[t]{2}{*}{0.008} \\
\hline & II & 168 & 183.93 & 49.06 & 176.46 & \\
\hline \multirow[t]{2}{*}{ LDL-Cholesterol (mg/dL) } & $\mathrm{I}$ & 316 & 104.62 & 33.04 & 100.96 & \multirow[t]{2}{*}{0.098} \\
\hline & II & 165 & 110.43 & 42.27 & 103.93 & \\
\hline \multirow[t]{2}{*}{ HDL-Cholesterol (mg/dL) } & $\mathrm{I}$ & 321 & 47.52 & 14.42 & 45.94 & \multirow[t]{2}{*}{0.075} \\
\hline & II & 167 & 50.22 & 18.31 & 47.42 & \\
\hline \multirow[t]{2}{*}{ Trygliceride (mg/dL) } & $\mathrm{I}$ & 322 & 104.80 & 58.16 & 98.42 & \multirow[t]{2}{*}{0.032} \\
\hline & II & 168 & 116.68 & 58.15 & 107.83 & \\
\hline \multirow[t]{2}{*}{ Thyroid Stimulating Hormon (UI/mL) } & I & 23 & 2.44 & 2.81 & 1.22 & \multirow[t]{2}{*}{0.692} \\
\hline & II & 12 & 3.02 & 5.84 & -0.69 & \\
\hline \multirow[t]{2}{*}{ C Reactive Protein (mg/dL) } & I & 158 & 29.30 & 45.71 & 22.11 & \multirow[t]{2}{*}{0.503} \\
\hline & II & 76 & 25.08 & 43.60 & 15.12 & \\
\hline \multirow[t]{2}{*}{ Serum creatinine (mg/dL) } & $\mathrm{I}$ & 329 & 1.19 & 0.53 & 1.13 & \multirow[t]{2}{*}{0.499} \\
\hline & II & 178 & 1.15 & 0.58 & 1.07 & \\
\hline
\end{tabular}

HDL: high density lipoprotein; LDL: low density lipoprotein.

1.83-7.46) showed a significantly higher estimated riskfor AF (as shown in table 3).

\section{Biological parameters}

Blood tests(shown Table 4) showed elevated cholesterol and trygliceride levels in patients from control group, while for LDL-cholesterol, HDL-cholesterol, thyroid stimulating hormone, $C$ reactive protein and creatinine values did not.

Mean value of CHA2DS2-VASC and HAS-BLED was 3,05 \pm 1.54 and $2.38 \pm 0.97$, respectively. Mean CHA2DS2-VASC and HAS-BLED score value were significantly higher in the study group: 3.19 vs. $2.79 ; P=0.006$, and 2.44 vs $2.27 ; P=$ 0.05 , respectively. In this study, $82 \%$ of patients have had CHA2DS2VASc score $\geq 2$; only $52 \%$ of these patients received appropriate anticoagulation treatment.

A slightly higher estimated risk of valve disease was noted in patients who associated: hypercholesterolaemia ( $R R=1.25$, IC95\%: 0.99-1.56), hypertriglyceridaemia (RR $=1.30$, IC95\%: 0, 45-3, 47) and right bundle branch block $(R R=1.21$; IC95\%: 0.42-1.37).
Patients with non-valvular AF, left-sided valve disease (excluding mitral stenosis and protheses) have a higher CHA2DS2VASc score [15]. Therefore, patients with nonvalvular AF seems to be a heterogenous group of patients with possible clinical significantly different from those without hemodynamic significant valvular heart disease. The profile of these patients is shown in table 6. They are older, with less comorbidity like obesity and chronic coronary disease, higher thromboembolic and hemoragic risk. The last ones could mean a w orse prognosis for these patients.

Diabetes mellitus and dyslipidemia were statistically significantmore frequent in patients from the control group. In these patients we found a significantly higher estimated risk for $\mathrm{AF}$.

In clinical practice in patients with non-valvular AF is mandatory to assess thromboembolic risk score by CHA2DS2VASc. Patients with CHA2DS2VASc score 0 have an annual risk of thromboembolic events not 0 . This might be due to the heterogeneity of non-valvular AF patients and hemodynamic significant valvular heart disease (other 


\begin{tabular}{|l|l|l|l|}
\hline PARAMETER & $\begin{array}{c}\text { Study group } \\
(\mathrm{N}=333)\end{array}$ & $\begin{array}{c}\text { Control group } \\
(\mathrm{N}=180)\end{array}$ & $\mathrm{P}$ \\
\hline Ages70 years (\%) & 61.0 & 37.8 & 0.001 \\
\hline Smoker (\%) & 18.9 & 26.7 & 0.044 \\
\hline Diabetes Mellitus (\%) & 17.4 & 31.1 & 0.001 \\
\hline Dyslipidemia (\%) & 11.4 & 18.3 & 0.033 \\
\hline Chronic Coronary Disease (\%) & 3.3 & 12.2 & 0.001 \\
\hline Mean CHA2DS2-VASc & $3.19 \pm 1,53$ & $2.79 \pm 1.52$ & 0.006 \\
\hline Mean HAS-BLED & $2.44 \pm 0.95$ & $2.27 \pm 0.99$ & 0.05 \\
\hline
\end{tabular}

Table 5

CLINICAL PROFILE OF PATIENTS WITH NON-VALVULAR ATRIAL FIBRILLATION

AND HEMODYNAMIC SIGNIFICANT VALVULAR HEART DISEASE than those with valvular prosthesis or rheumatic mitral valve disease) $[16,17]$.

\section{Limitations}

This study has the limitations of an observational retrospective analysis with many variables which were analysed. In this there was a control group.

\section{Conclusions}

In patients with non-valvular AF and hemodynamic significant valvular heart disease, dyslipidemia showed a significantly higher estimated risk for AF, as well as diabetes mellitus and coronary heart disease. Therefore these patients, beyond the curent guidelines, could have a completely different profile and prognosis.

\section{References}

1.QIAN, Y., MENG, J., TANG, H., YANG, G., DENG, Y., WEl, D., et al., Europace,12, 2010, p. 371

2.CAMM, A.J ., LIP, G.Y., DE CATERINA, R., SAVELIEVA, I., ATAR, D., HOHNLOSER, S.H., et al.. Europace,14, 2012, p. 1385

3.WIDGREN, V., DENCKER, M., JUHLIN, T., PLATONOV, P., WILLENHEIMER, R., BMC Cardiovasc Disord,12, 2012, p. 92

4.SCARSOGLIO, S., SAGLIETTO, A., GAITA, F., RIDOLFI, L., ANSELMINO, M., Peer] ,4, 2016, e2240
5.LUO, Z.Q.,HAO, X.H.,L.I., J.H, DAI, J ., LIU, K.Y., LAI, Y.Q.,J Thorac Cardiovasc Surg,148, 2014, p. 1970

6.ZONI-BERISSO, M., LERCARI, F., CARAZZA, T., DOMENICUCCI, S., Clin Epidemiol.,6, 2014, p. 213

7.BREITHARDT, G., BAUMGARTNER, H., Eur Heart J,36, 2015, p. 1794 8.DAHL, J.S., BRANDES, A., VIDEB/EK, L., POULSEN, K.M., CARTERSTORCH, R., CHRISTENSEN LN, et al. IJ C Heart \&Vessels,4, 2014, p. 102

9.FUSTER, V., RYDEN, L.E., CANNOM, D.S., CRIJ NS, H.J ., CURTIS, A.B., ELLENBOGEN, K.A., et al. Europace, 8, 2006, p. 651 10.J ANUARY, C.T., WANN, L.S., ALPERT, J.S., CALKINS, H., CIGARROA, J.E,, CLEVELAND, J.C. Jr, et al.Circulation,130, 2014, 2071

11.MOLTENI, M., POLO, FRIZ, H., PRIMITZ, L., MARANO, G., BORACCHI, P., CIMMINIELLO, C., Europace,16, 2014,1720

12.HIRSH, B.J., COPELAND-HALPERIN, R.S., HALPERIN, J.L., J Am Coll Cardiol.,65, 2015, p. 2239

13.GUICHARD, J.B., NATTEL, S., J Am Coll Cardiol.,70, 2017, p. 756 14.LIP, G.Y., WINDECKER, S., HUBER, K., KIRCHHOF, P., MARIN, F., TEN, BERG, J.M., et al.,Eur Heart J.,35, 2014, 3155

15.PHILIPPART, R., BRUNET-BERNARD, A., CLEMENTY, N., BOURGUIGNON, T., MIRZA, A., BABUTY, D.,et al. Eur Heart J., 36, 2015, p. 1822

16.Di BIASE, L., J Am Heart Assoc.,5, 2016,pii: e002776

17.POTPARA, T.S., LIP, G.Y., LARSEN, T.B., MADRID, A., DOBREANU, D., JEDRZEJ CZYK-PATEJ, E., et al. Europace,18, 2016, p. 1593

$\overline{\text { Manuscript received: } 7.07 .2019}$ 